\title{
Queering Brexit
}

\section{How little can Little Britain get?}

On 24 June 2016, many people had the feeling that they had gone to bed the night before in the United Kingdom and had woken up in Little Britain - a country prone to isolationism and protectionism, risking hurting its economic and social development for the sake of imperial nostalgia and moral panic about 'loss of sovereignty' and 'mass migration'. That feeling inevitably affected many individuals who identify as lesbian, gay, bisexual, trans, intersex, queer and other (LGBTIQ+). Although the possible impact of Brexit seems to have been scrutinised from most angles, there has been limited analysis of how it may affect LGBTIQ+ individuals.

There is certainly more than one 'gay in the village', so it is worth assessing Brexit in relation to the situation of LGBTIQ+ individuals. This is particularly timely in the light of the recent UK Supreme Court decision in Walker v Innospec Limited, where the Court relied on European Union (EU) law to hold a provision of the Equality Act 2010 unlawful for violating pension rights of same-sex couples.

\section{What has the European Union ever done for us queers?}

The EU has often been viewed as 'the' sexual minorities' champion. Whether or not this is entirely true, it has certainly been instrumental in pushing ahead the LGBTIQ+ agenda in EU member states, including the United Kingdom.

Following the reform of the European Treaties in 1997, the EU was able to take concrete, although minimum, actions to improve LGBTIQ+ people's lives. Not only did the EU foster a cultural change in all member states, but it also introduced legal obligations that went far beyond their original scope. To mention one example, the Equality Framework Directive 2000/78, which prohibits a range of forms of discrimination in the field of employment, has been read and applied through an 'antistereotyping approach' by the Court of Justice of the EU (CJEU) and, consequently, throughout the Union. For the first time, discrimination was detected in the case of public statements that reproduced popular clichés of homosexuality. As a result, such statements have been held unlawful when used to de facto hamper (actual or presumed) gay people from being employed (see Accept). By the same token, employees' civil status has been deemed irrelevant as the basis for distinctions between employees if it reflects sexual orientation discrimination. Hence, measures such as pensions, special leaves, etc., aimed to support employees' families, cannot be denied to LGB(T) employees only because they are not married (or cannot marry) (see Maruko, Römer, Hay). In fact, marriage has been identified by EU judges as a heteronormative notion that embeds 'in itself' stigma and discrimination against LGB people in countries where marriage is restricted to opposite-sex couples (see again $\underline{\text { Hay }}$ ).

If we add that the EU Parliament has shown an interest in developing an interconnected and comprehensive set of measures in most spheres of life of LGBTIQ+ people through a SOGI Roadmap, then we can see that the EU has started down the path towards full recognition of LGBTIQ+ people's 'social' dignity. This is even clearer if we consider the EU's commitment to grant international protection to people fleeing homophobia outside the Union, demonstrated in the CJEU's decisions in $\underline{X, Y \text { and } Z}$ and $\underline{A, B \text { and } C}$.

It goes without saying that the UK will not be obliged to follow this path after Brexit. Considering also that the EU will lose an 'LGBTIQ+ friendly' member state, with clear implications on the internal 
consensus for pushing ahead the equality agenda, then LGBTIQ+ people both in the UK and elsewhere in the EU may suffer from Brexit.

\section{God save the... queers?}

Focusing on the UK, it was the EU's Equality Framework Directive 2000/78 which acted as the spark for a change of direction in domestic discrimination law directly benefitting LGBTIQ+ people. LGBTIQ+ individuals and communities have seen significant progress since the turn of the century and much of it can be attributed to the UK's membership (understood in its broadest sense) of the EU and the benefits derived from this in terms of a) law and policy, b) funding and broader capacitybuilding, and c) solidarity between activists and civil society organisations across Europe.

In the first of these areas, the Equality Framework Directive was the catalyst for a new direction in UK policy and law - which had hitherto been largely punitive and discriminatory (think of, say, the Section 28 prohibition on the 'promotion of homosexuality' by schools). The directive sparked a series of government white papers, legislative reviews and stakeholder debates that ultimately went beyond the requirements of EU law. These culminated in the establishment of an equality body and the Equality Act 2010, both of which were founded on tackling discrimination on the basis of nine protected characteristics, including sexual orientation and gender reassignment, and enshrining a duty on public bodies not only to prevent discrimination but also to advance equality of opportunity (something that, notably, did not derive from European Union law).

Furthermore, EU funding has been crucial for organisations which support activities to raise awareness of discrimination and develop tools to tackle it, for example through the Progress funding programme, or through the surveys and reports commissioned by the Fundamental Rights Agency. And finally, UK membership of the EU has brought engagement with many NGOs and networks of NGOs working in partnership across Europe to tackle LGBTIQ+ discrimination and hate crime - often with the financial support of the Commission, such as ILGA Europe.

Once outside the EU, the UK may not be nudged by new laws, regulations and other initiatives into tackling discrimination to the same extent as it is now.

\section{Hard, soft or no fall?}

What will happen to LGBTIQ+ rights when the UK formally leaves the EU is obviously an exercise in futurology. Yet, one thing is clear: the fall is very likely to be hard for LGBTIQ+ individuals and anyone else relying on discrimination law to protect them, especially considering the decade-long appalling record of the Conservative Party on equality policies. In light of the Great Repeal Bill recently approved in the Commons and Theresa May's well-known wish to withdraw from the European Convention on Human Rights, not only might a future government erode EU-derived norms that currently protect LGBTIQ+ individuals, but where this results in a human rights violation, it might also try to deprive them of the possibility of resorting to the European Court of Human Rights.

Although it is theoretically possible that the UK will not attempt to regress in terms of the achievements described above, LGBTIQ+ individuals, organisations and communities should be well aware of one thing: they will most likely be deprived eventually of a number of pathways to justice and more progressive policies. To compensate, they will need to step up the domestic fight and build new forums for international cooperation. Red alert it is. 
[pre-print version of Danisi, Carmelo, Dustin, Moira and Ferreira, Nuno (2017) Queering Brexit. The UK in a Changing Europe, available online: http://ukandeu.ac.uk/queering-brexit/]

Dr Carmelo Danisi, Research Fellow at the University of Sussex and Adjunct Professor at the University of Bologna

Dr Moira Dustin, Research Fellow at the University of Sussex

Professor Nuno Ferreira, Professor of Law at the University of Sussex

The authors are members of SOGICA, a four-year (2016-2020) research project funded by the European Research Council (ERC) that explores the social and legal experiences of asylum seekers across Europe claiming internal protection on the basis of their sexual orientation or gender identity (SOGI). The authors plan to release a longer analysis on the theme of this blog piece in a collection to be published in 2018, currently being co-edited by Moira Dustin, Nuno Ferreira and Susan Millns. 